\title{
Design and Operation of the Artificial-Recharge Plant at Bay Park, New York
}

GEOLOGICAL SURVEY PROFESSIONAL PAPER 751-B

Prepared in cooperation with the Nassau County Department of Public Works

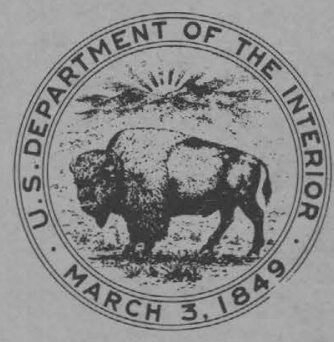





\section{Design and Operation of the Artificial-Recharge Plant at Bay Park, New York}

By ELLIS KOCH, ANTHONY A. GIAIMO, and DENNIS J. SULAM

DEEP-WELL ARTIFICIAL-RECHARGE EXPERIMENTS AT BAY PARK, LONG ISLAND, NEW YORK

GEOLOGICAL SURVEY PROFESSIONAL PAPER 751-B

Prepared in cooperation with the Nassau County Department of Public Works

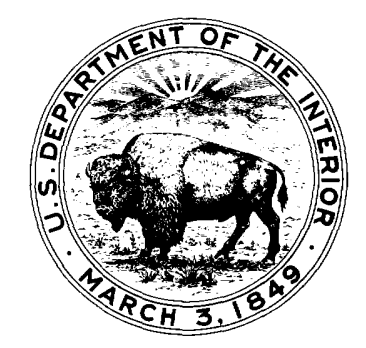




\section{UNITED STATES DEPARTMENT OF THE INTERIOR \\ ROGERS C. B. MORTON, Secretary}

\section{GEOLOGICAL SURVEY}

V. E. McKelvey, Director

Library of Congress catalog card-No. 73-600073

For sale by the Superintendent of Documents, U.S. Government Printing Office Washington, D.C. 20402 - Price 95 cents domestic postpaid or 75 cents GPO Bookstore Stock Number 2401-00321 


\section{CONTENTS}

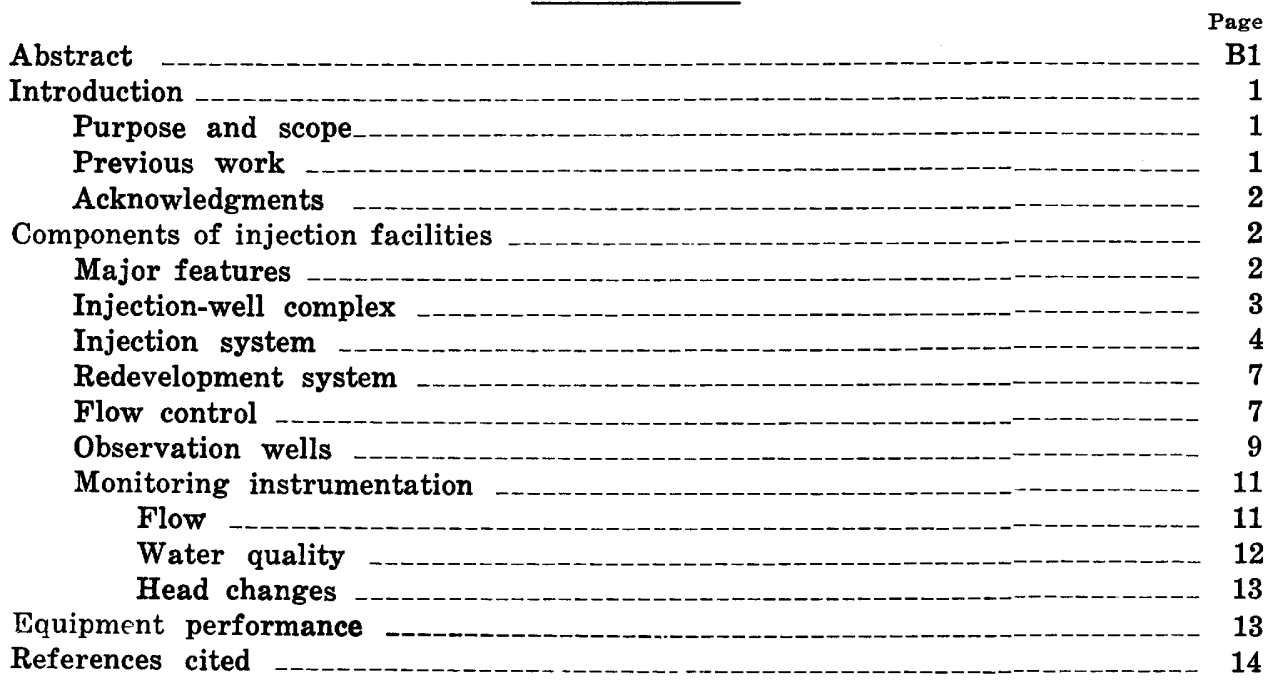

\section{ILLUSTRATIONS}

Plate 1. Diagram showing major elements of the recharge plant and flow

FIgURE 1. Map of Long Island and vicinity showing location of the artificial-

\section{route of the water during injection or redevelopment, Bay Park,} recharge site

2. Photograph of recharge facility

3. Diagram showing construction details of the injection-well complex -

4. Photograph of sand-filled probe

5. Photograph of injection pump

6. Schematic showing the operation of the flow-monitoring and flowcontrolling systems

7. Photograph of flow-controlling and flow-monitoring console in wellhouse ---

8. Site plan showing location of observation wells, structures, and external piping -

9. Hydrogeologic section of artificial-recharge site showing vertical and horizontal distribution of the observation-well screens in relation to the injection-well screen -

10. Schematic of sampling line for continuous monitoring of water quality

\section{TABLE}

TABLE 1. Selected construction details of test and observation wells 



\title{
DESIGN AND OPERATION OF THE ARTIFICIAL-RECHARGE PLANT AT BAY PARK, NEW YORK
}

\author{
By Ellis Kogh, Anthony A. Giaimo, and Dennis J. Sulam
}

\begin{abstract}
The Bay Park artificial-recharge plant, in southwestern Nassau County, is an extensively instrumented facility adjacent to a 60 -million gallon-per-day sewage-treatment plant. The facility was constructed to inject reclaimed water (sewage-plant effluent that has been given tertiary treatment) into a deep well in the Magothy aquifer and to monitor hydraulic and geochemical effects of that water on the aquifer, the major source of water for Nassau County. An array of observation wells permits monitoring those effects at distances up to 200 feet from the injection well. Major components of the facility include: (a) a 50,000-gallon storage tank, (b) a vacuum degasifier, (c) pumping and ccntrolling equipment for maintaining injection either at a constant rate or under a constant head, (d) flow-rate and water-quality monitoring and recording equipment, (e) a 490-foot-deep injection well, (f) an array of observation wells, and $(\mathrm{g})$ pumping equipment for testing and redeveloping the injection well.

Effluent can be injected at rates as much as 400 gallons per minute and the injection well can be redeveloped at rates as much as 1,000 gallons per minute.

Casings of the injection well and of most of the observation wells are made of fiber-glass-reinforced epoxy pipe. One of the well screens is made of slotted fiber-glass-reinforced epoxy pipe; the others are made of stainless steel. Associated piping and tanks are made either of polyvinyl chloride or of steel coated with chemically stable materials, such as epoxy or coal-tar enamel. These materials were selected to minimize corrosion of tanks. pipes, and screens exposed to reclaimed water or to chemical solutions used in redevelopment of the injection well.

The chemical character of the water to be injected can be changed by the addition of chemicals at the storage tank's inlet or outlet and by the degasification process. Automatic sensors continuously monitor injection water, repumped water, or water from observation wells for temperature, turbidity, specific conductance, $\mathrm{pH}, \mathrm{Eh}$, and dissolved-oxygen and residual-chlorine contents. In addition, periodic calibration of the automatic sensors as well as some chemical and bacteriological analyses can be made in a small laboratory at the site.
\end{abstract}

\section{INTRODUCTION}

\section{PURPOSE AND SCOPE}

The Bay Park artificial-recharge study was begun in 1964 as part of a cooperative program of waterresources investigations by the U.S. Geological Survey and the Nassau County Department of Public Works. The study involves experimental injection of reclaimed water (sewage-plant effluent that has been given tertiary treatment) into a 490 -foot-deep well in the Magothy aquifer. The recharge facility is in southwestern Nassau County (fig. 1), in the Village of East Rockaway, on the property of the Bay Park sewage-treatment plant.

The Bay Park sewage-treatment plant is the activated-sludge type. It has a design capacity of $60 \mathrm{mgd}$ (million gallons per day). About $0.6 \mathrm{mgd}$ of the effluent from this plant is diverted to a pilot plant, where it receives tertiary treatment. There the effluent is clarified; filtered, first through sand-anthrafilt beds and then through beds of activated carbon; and chlorinated. About 425,000 gallons of the treated effluent from the pilot plant (reclaimed water) is then piped to the recharge facility (fig. 2).

This report, one of a series on the experimental results at Bay Park, describes the design and the operation of the recharge plant.

\section{PREVIOUS WORK}

Several reports on the Bay Park facility and its operation have been published. Cohen and Durfor (1966) described the injection well in detail. In a subsequent report, Cohen and Durfor (1967) listed the objectives of the recharge study and described 


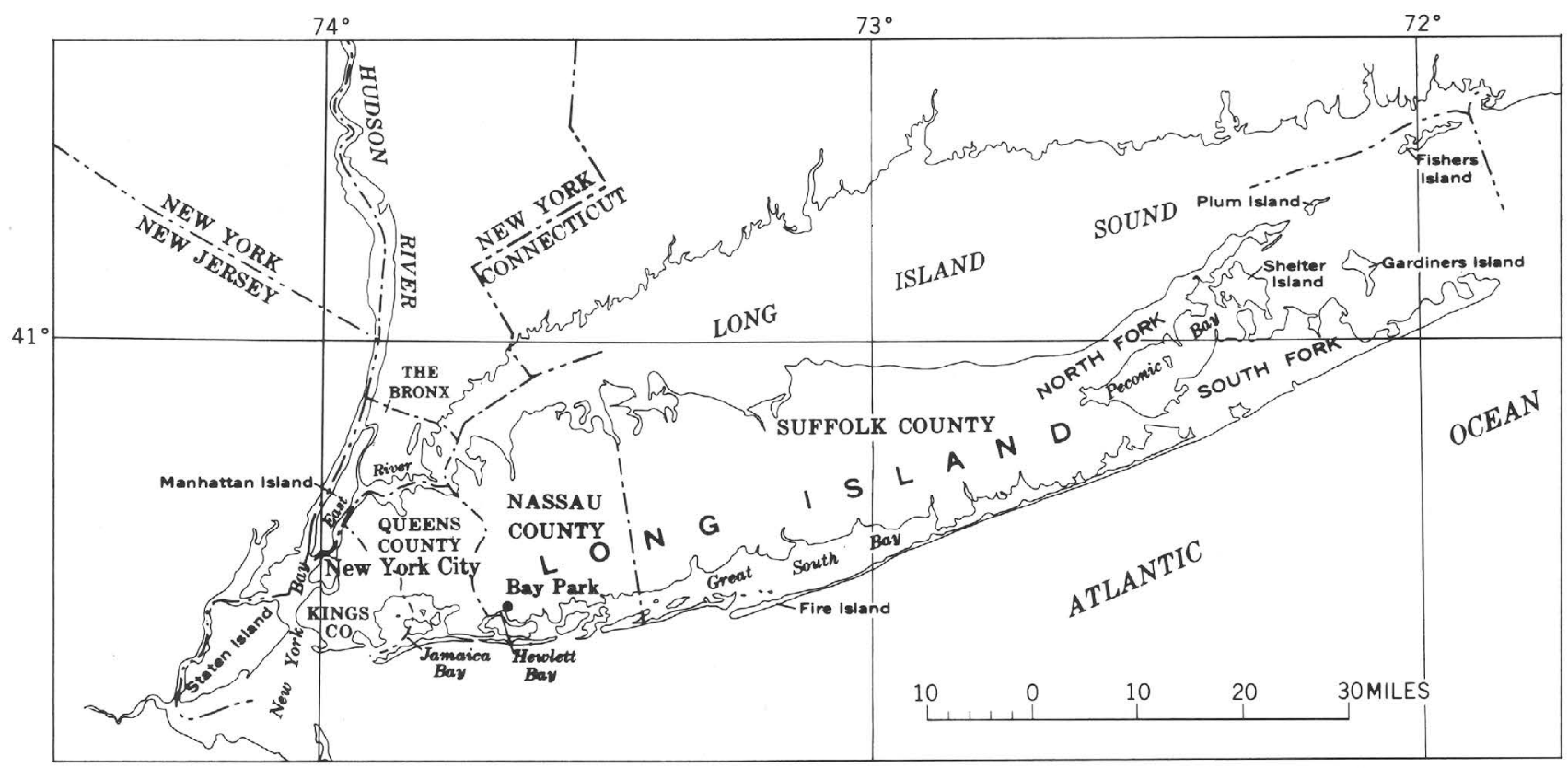

FIGURE 1.-Location of the Bay Park artificial-recharge site.

the injection equipment. Peters and Rose (1968) described the facility but concentrated on the sewagetreatment operation. Peters (1968) discussed the overall project and also commented on the early operation of the treatment and the injection plants. Perlmutter, Pearson, and Bennett (1968) described briefly the geology and the hydrology of the Bay Park site, the types of experiments, and the injection facility. Vecchioli and $\mathrm{Ku}$ (1970) discussed early injection tests in detail. Vecchioli (1970) commented briefly on bacterial growth around the injection well.

\section{ACKNOWLEDGMENTS}

The recharge facility was designed mainly by personnel of the U.S. Geological Survey. Certain engineering specifications were developed by, and some

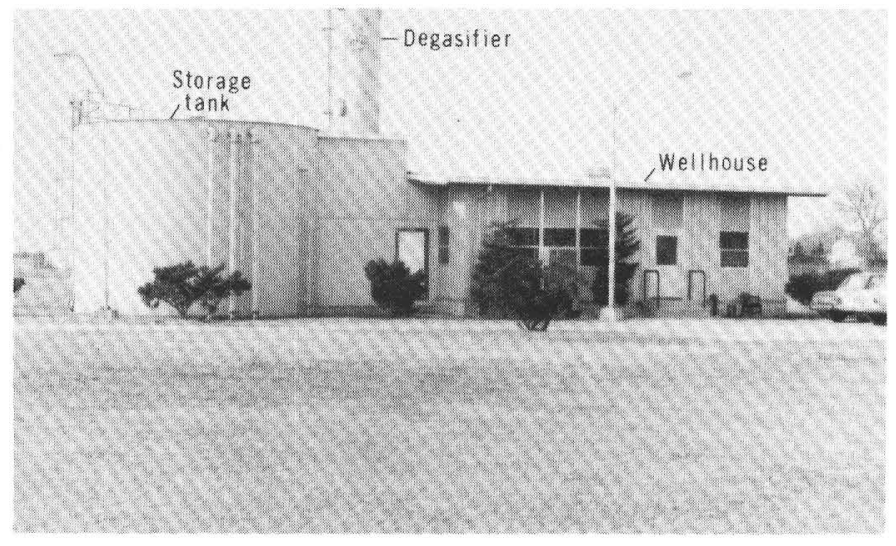

Figure 2.-Recharge facility at Bay Park. of the construction was supervised by, personnel of the Nassau County Department of Public Works and their engineering consultants, Burns and Roe, Inc. Individuals who had a major role in the experimental work at Bay Park include John H. Peters, Commissioner of the Nassau County Department of Public Works; John L. Rose of Burns and Roe, Inc.; and Philip Cohen, Charles N. Durfor, and Bruce L. Foxworthy of the Geological Survey. The testing of the operation of the plant and some early modifications to the equipment were done by Gordon D. Bennett and F. J. Pearson, Jr., of the U.S. Geological Survey. Bennett also prepared some preliminary descriptions of the equipment and of the operation of the recharge plant. Some later modifications to the plant were made under the supervision of John Vecchioli, Geological Survey project chief of the Bay Park study at this writing (1972).

Special thanks are given Commissioner John H. Peters, Francis J. Flood, and James A. Oliva of the Nassau County Department of Public Works for coordinating the treatment-plant operation with that of the recharge plant and also for providing manpower and equipment for maintenance and modification of the recharge plant. Without their day-to-day support, the continuing experiments would not be possible,

\section{COMPONENTS OF INJECTION FACILITIES MAJOR FEATURES}

The main function of the Bay Park artificialrecharge plant is to pump water into the Magothy 
aquifer by means of a deep well. Two types of water can be thus injected-either potable water from the local public-supply system or reclaimed water from the tertiary-treatment process. The ability to inject both types of water permits a comparison of well and aquifer response to the injection of potable water and reclaimed water. The quality of either type of water can be modified just before injection by adding chemicals at the inlet or the outlet of a storage tank (fig. 2) and (or) by passing the water through a degasifier (fig. 2).

The recharge facility also contains equipment for pumping water out of the injection well. Pumping water out of the well after a period of injection is somewhat analogous to backwashing a "sand filter," in that the normal direction of water flow is reversed. Some of the clogging material that accumulates around the well during injection is flushed out by the pumping. This redevelopment process insures at least a partial restoration of the original specific capacity of the well. The redevelopment pumping equipment also permits hydraulic testing of the injection well and the aquifer, both before and after injection tests, and it facilitates sampling of water from the aquifer for chemical and microbiological analyses.

For the detailed study of the effects of injection on the hydraulics and the geochemistry of the aquifer system, 18 observation wells were constructed. These wells are arrayed radially around the injection well at distances ranging from a few inches to 200 feet. Some observation wells are screened within the injection zone; the others are screened in zones above or below the injection zone.

The injection well, most of the observation wells, and all piping and tanks were constructed either of chemically inert materials or of ordinary materials that had been coated with epoxy or coal-tar enamel to minimize chemical reactions with either the water to be injected or the water from the aquifer. Products of such reactions would tend to clog the well screens and (or) adjacent aquifer materials.

The recharge facility contains instrumentation for automatic monitoring of flow rates during injection or redevelopment periods. Pertinent quality-of-water parameters can also be monitored automatically. A small laboratory in the wellhouse (fig. 2) facilitates on-site chemical and microbiological analyses of water samples.

Plant components and their functions are described in the following sections.

\section{INJECTION-WELL COMPLEX}

Various views of the injection-well complex are shown schematically in figure 3 . The materials used in the well and the method of drilling and emplacing the well were described at length by Cohen and Durfor (1966); hence, only major features of the well are discussed here.

The injection well is 490 feet deep. It consists of a fiber-glass-reinforced epoxy casing, 418 feet in length and 18 inches in diameter, above a stainlesssteel wire-wrapped screen, 62 feet in length and 16 inches in diameter. A stainless-steel sand trap, 10 feet in length, is attached to the bottom of the screen. The space between the screen and the face of the drill hole is filled with a filter pack composed of about 71 percent very coarse sand and 28 percent very fine gravel. The thickness of the filter pack is about 10 inches. The slot size of the screen, 0.060 inch, was chosen to retain about 80 percent of the filter pack.

Water to be injected can be routed into the injection-well casing either at land surface or at a depth of 192 feet. Inasmuch as the static water level in the well is about 5 feet below land surface, the deeper opening was provided to help avoid any cascading of water and possible air entrainment that might result from injection at land surface. The deeper opening also helps avoid turbulence resulting from flow around the redevelopment-pump column, which is suspended in the casing to a depth of 150 feet. A third possible injection opening is through the column of the redevelopment pump.

A 1-inch-diameter pipe enters the injection casing 3 feet above the screen, and another 1 -inch-diameter pipe taps the casing at land surface. Each of these is connected to a pair of water and mercury manometers, which give a visual readout of the head in the well. Hence, simultaneous observations can be made of the head at land surface and just above the screen.

Three pipes enter the injection casing through a steel plate that caps the well. One is the column of the redevelopment pump; the other two are used to lower instruments into the well, collect "grab-samples" of water at specific depths, or collect samples of sediment from the sand trap at the bottom of the well. Of the latter two pipes, one is 6 inches in diameter and opens directly into the casing at the well head. The other is an open-ended, 4-inch-diameter pipe, called the instrument-access pipe, which extends to a depth of 250 feet. The instrument-access pipe is used to circumvent the possibility of 
entangling down-hole instruments around the column and bowls of the redevelopment pump. The major use of this pipe has been to lower a deep-well current meter into the screen zone during redevelopment and injection. Measurements made with this meter along sections of the screen made possible the drawing of velocity profiles, from which were determined the relative hydraulic conductivities of the various beds in the screen zone. During injection, a watertight fitting is attached to the top of the instrument-access pipe to minimize leakage when the current meter is raised and lowered. The instrument-access pipe has also been used in lowering geophysical well-logging probes into the well.

A 4-inch-diameter observation well-known as the annular-space well (well N7885) -is installed approximately in the middle of the filter pack of the injection well (fig. 3). The vertical dimensions of the components of this well are the same as those of the injection well. This annular-space well is used to monitor water-level and water-quality changes in the filter pack. Because of the positive head developed in this well during injection, water flows from it at land surface. This facilitates collection of samples. To decrease the time of travel of the water from the screen of the annular-space well to land surface, a $1 / 2$-inch pipe was suspended in the well to the top of the screen. Rapid displacement of the small volume of water in this pipe facilitates the collection of water samples more representative of water in the filter pack.

In some injection tests the $1 / 2$-inch sampling line was removed from the annular-space well, and a sand-filled probe was suspended opposite the screened interval. The sand-filled probe (fig. 4) consists of a 2-inch-diameter stainless-steel wirewrapped well point that is 27 inches long. It is filled with sand taken from the injection zone during the drilling of the well. The probe has been used in the study of induced bacterial growth in the injection zone associated with the injection of the reclaimed water.

During injection, head changes in the annularspace observation well are monitored with a water and (or) a mercury manometer. Water samples can be collected from a tap on the pipe leading to the water manometer.

\section{INJECTION SYSTEM}

Water to be injected is delivered into a 50,000-gallon storage tank through either of two 6-inch-diameter lines that enter the tank near its top (see pl. 1).
EXTERIOR VIEW OF INJECTION-WELL COMPLEX (from Cohen and Durfor 1956, P. D254)

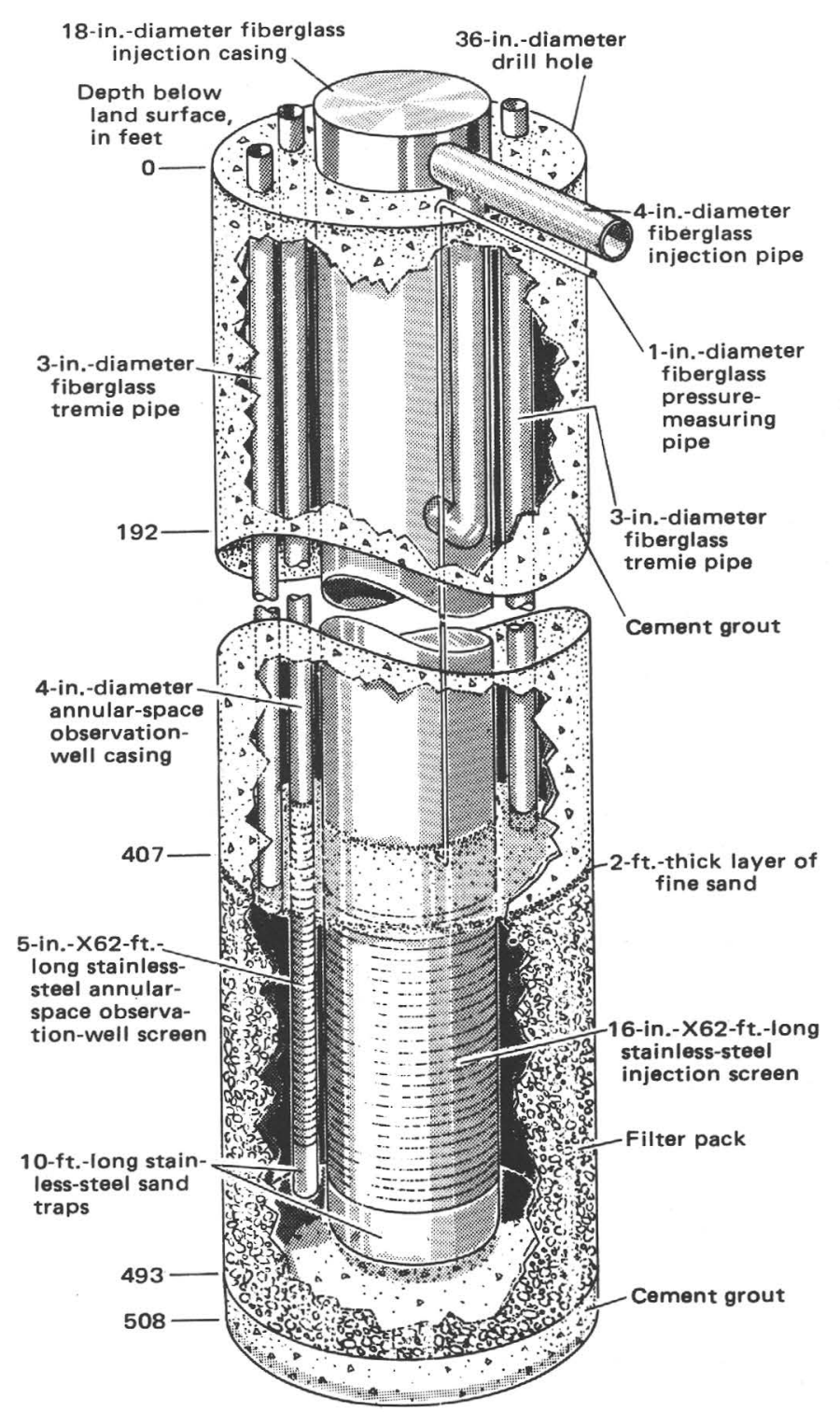

FIGURE 3 (Above and right.) - Schematic of injection-well complex.

One line delivers water from the public-supply system. The other delivers the effluent from the tertiary treatment plant. Water discharges from these lines into an open rectangular box, called the splashbox, attached to the inside of the storage tank near its top. The splashbox serves as a small mixing tank for chemicals that can be added to the injection water as desired. Two $3 / 8$-inch-diameter pipes feed chemicals from vats in the basement of the wellhouse to the splashbox. Another set of chemical-feed lines is attached to the outlet pipe of the storage tank. Although adding chemicals at the splashbox assures 


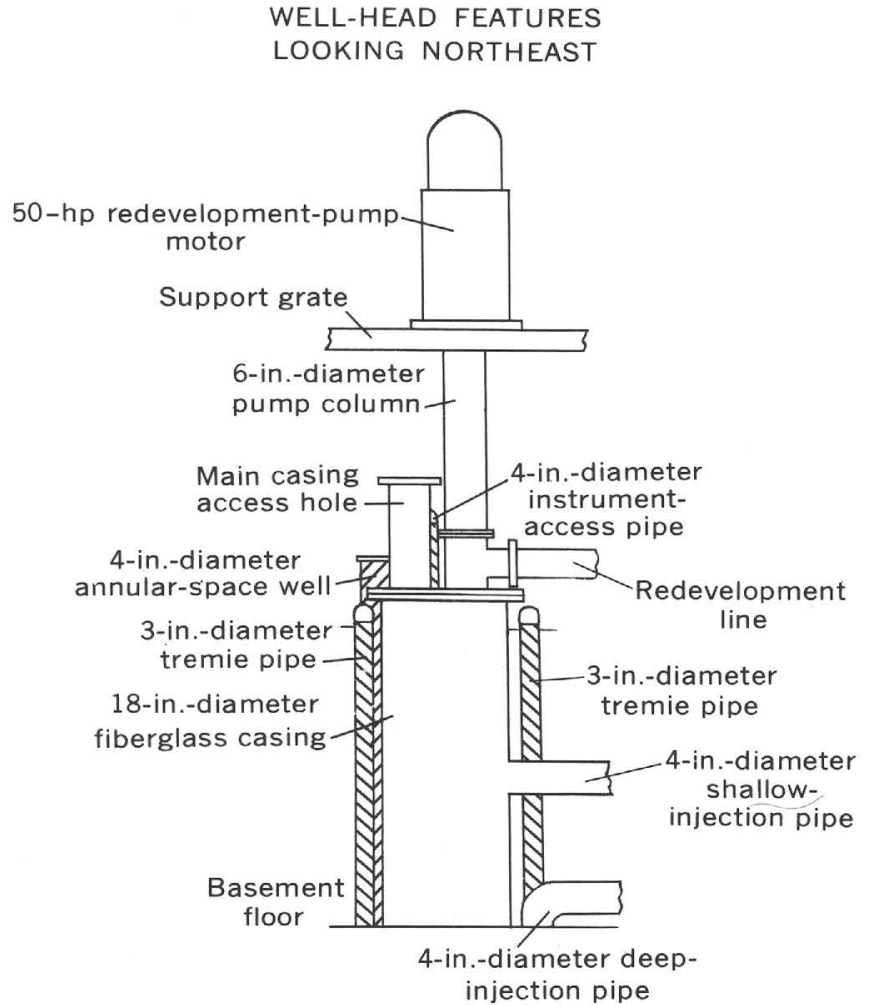

even mixing of chemicals with the water, aeration of the water prematurely oxidizes certain reducing agents, such as sodium sulfite, that have been added during two experiments. Adding the chemicals at the tank outlet reduces preinjection contact time and precludes premature oxidation. Accordingly, during most of the experiments in which chemical additives were used, the chemicals were introduced at the tank outlet.

A 4-inch-diameter overflow line rises to a height 4 feet below the top of the storage tank, the same height as the bottom of the splashbox. The overflow line can dispose of water at a rate of $600 \mathrm{gpm}$ (gallons per minute) by gravity flow.

After leaving the storage tank through a 6 -inchdiameter outlet pipe, water to be injected can be routed either through the degasifier (fig. 2 and pl. 1) or directly to the injection pump.

The degasifier, shown diagrammatically in plate 1 , removes dissolved gases and entrained air from the injection water. It is a tank 4 feet in diameter and 25 feet in height. The top of the tank is connected to a 5 -hp (horsepower) vacuum pump by a 3 -inch-diameter pve (polyvinyl chloride) pipe. The vacuum pump is in the basement of the wellhouse. Water enters the side of the storage tank near its top through a 6-inch-diameter pve pipe. A nozzle assembly at the end of this pipe breaks the stream of
PLAN VIEW OF INJECTION-WELL COMPLEX

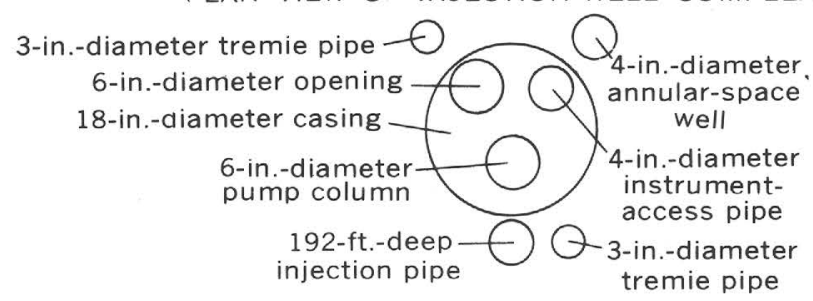

INTERIOR VIEW OF INJECTION CASING Depth below land surface in feet
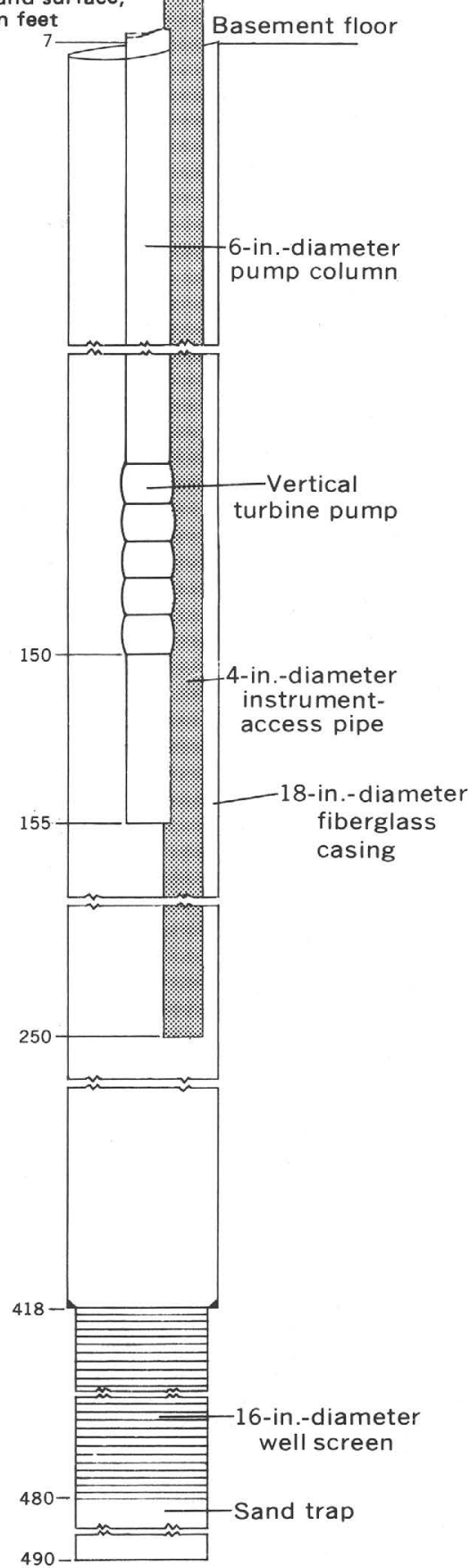
water into a spray that then falls through two 4foot-thick beds of raschig rings. A raschig ring is a 1-inch-diameter ceramic cylinder, 1 inch high, with walls $1 / 8$ inch thick. The beds are composed of randomly oriented rings. These beds cause turbulent flow, which further increases the surface area of the water droplets and assures maximum removal of the dissolved gases. The liberated gases are drawn out of the tank by the vacuum pump. A demisting assembly just below the top of the degasifier removes any suspended water from the gases being evacuated from the tank. The demisting assembly is 4 feet in diameter and consists of a 4-inch-thick core of fine stainless-steel mesh with a 1-inch-thick stainlesssteel grid on either side.

Flow from the storage tank into the degasifier was accomplished at first simply by vacuum lift. However, the rate of flow was found to depend on the level of water in the storage tank. As the level in the storage tank dropped in response to brief scheduled

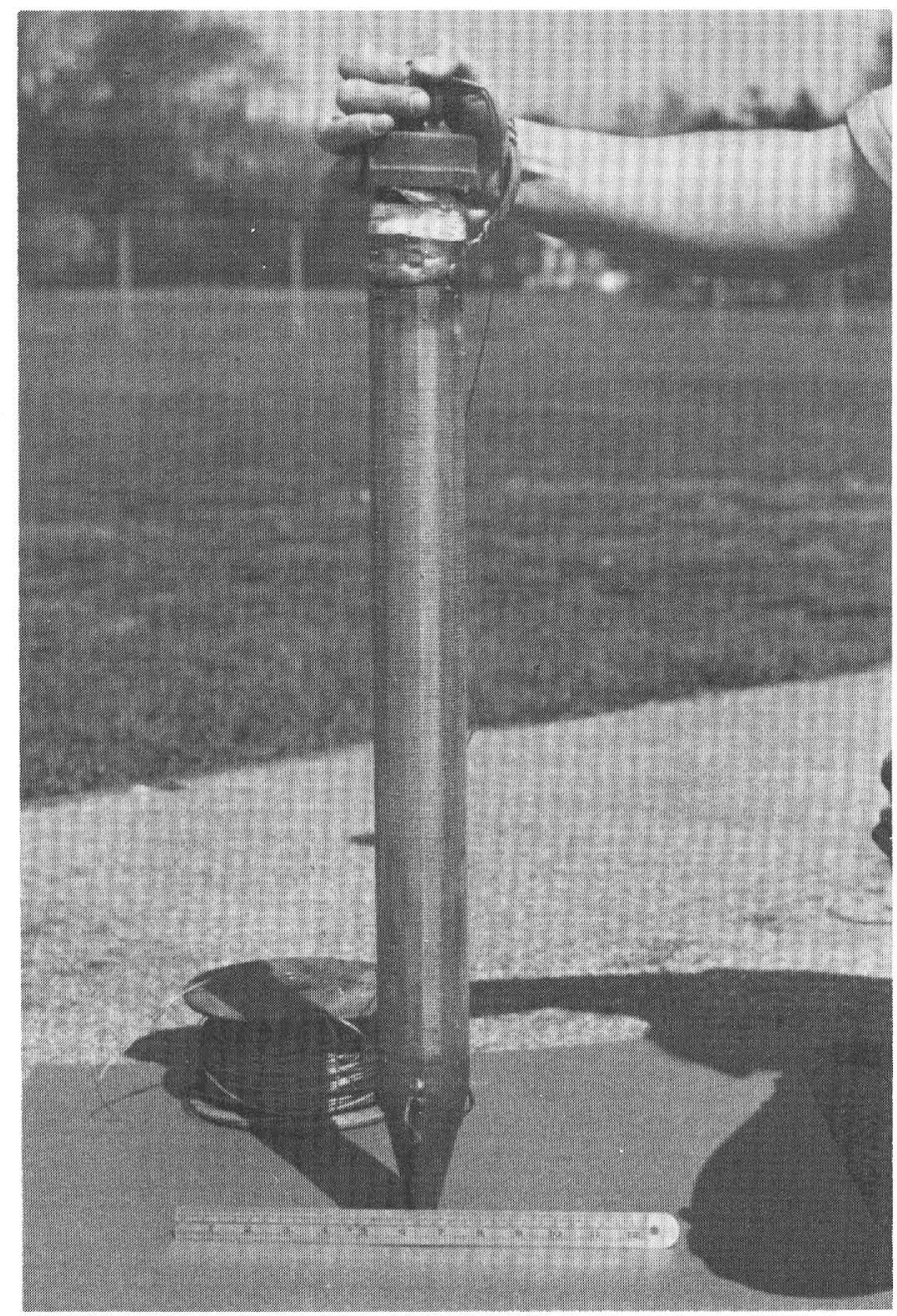

Figure 4.-Sand-filled probe. shutdowns of the tertiary-treatment plant, the rate of flow decreased to as little as $185 \mathrm{gpm}$. A centrifugal booster pump was installed later to assure a continuous rate of flow to the degasifier of at least $400 \mathrm{gpm}$, which is the design injection capacity. A butterfly valve in the line on the discharge side of the booster pump regulates the flow into the degasifier.

Float-operated controls are positioned inside the degasifier to maintain the water level within the proper operating range. If the water level dropped too low, the injection pump would run dry and would be damaged. Therefore, a switch shuts off the injection pump whenever the water level in the degasifier falls to within $2 \frac{1}{2}$ feet of the bottom. This is called the low water-level control. If the level rises too high, degasing efficiency decreases. Moreover, if the degasifier becomes filled with water, the vacuum pump will be flooded and will be damaged. A high water-level control prevents this from happening by closing the butterfly valve.

The high water-level control is a switch that both closes and opens the butterfly valve when the level in the degasifier tank rises above or falls below preset limits. When the tank level rises above the maximum limit, a pneumatic signal closes the butterfly valve. At the same time, a signal stops the vacuum pump. This double precaution protects the vacuum pump from flooding if the butterfly valve malfunctions. When the water level in the degasifier drops below a preset limit, a pneumatic signal opens the butterfly valve and also reactivates the vacuum pump. Another switch inside the degasifier starts the vacuum pump when the vacuum falls below 28.5 inches of mercury. This switch is wired in series with the high-level control so that the vacuum pump can be started only when the water level in the degasifier is below the maximum limit. The water level in the tank can be monitored by observation of the level in a glass-viewing pipe attached to the degasifier (pl. 1).

The vacuum pump is a single-stage rotary piston pump powered by a 5 -hp motor through a belt drive. The pump is vented to the outside of the building by a 21/2-inch-diameter pvc pipe. A lubricating and sealing oil is fed into the piston. This oil is discharged through the pump exhaust with the gases evacuated from the degasifier. The oil, contaminated by condensed water vapor, is collected from the exhaust pipe and is returned to a reservoir. A gas-ballast valve admits a small quantity of atmospheric air to the piston chamber, and this keeps condensation to a minimum. The water returned with the oil to the 
reservoir separates from the oil and collects on the bottom of the reservoir, where it is drawn off by a siphon. Periodic additions of oil to the reservoir are needed to replace some of the oil that is lost through the exhaust. The gas-ballast system has been fitted with a solenoid valve that is open only when the vacuum pump is operating. The arrangement prevents air from leaking in through the piston and deteriorating the vacuum in the degasifier. The vacuum pump is water-cooled, and the supply to the cooling jacket is controlled by another solenoid valve which permits cooling water to flow only when the pump is operating.

The degasifier can be bypassed, if desired, and the flow can be routed directly to the injection pump. When the degasifier is bypassed, the low-level control is switched automatically to the storage tank. A check valve positioned in the line directly before the injection pump prevents reverse flow of the water if the pump is shut down.

The injection-pump assembly consists of a $40-\mathrm{hp}$ electric motor connected to a centrifugal pump through a variable-speed hydraulic transmission. This system, which is depicted in figure 5, allows the injection rate to be controlled in the range from zero to more than $400 \mathrm{gpm}$ against a maximum head of 100 psi (pounds per square inch). At the injection pump, the diameter of the pipe decreases from 6 to 4 inches. The water leaving the injection pump can go to one of three places: to waste by way of the local storm sewer; to the injection well; or to the recirculation line, a 6-inch-diameter pipe running back to the splashbox in the storage tank (pl. 1). By use of the recirculation line, water can be pumped in a loop through the degasifier and the injection pump and then back to the storage tank. This is useful to test

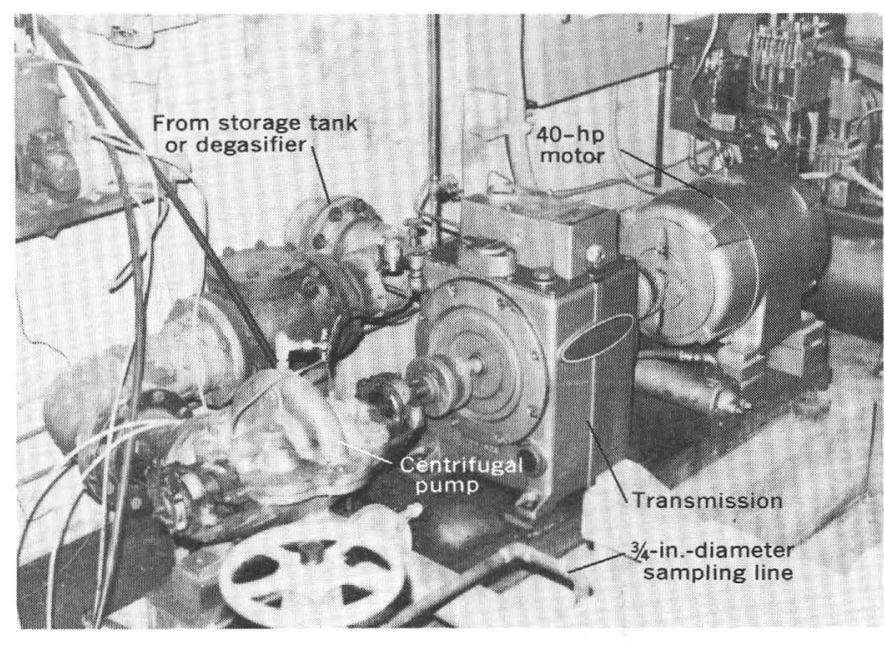

Figure 5.-Injection pump. these pieces of equipment without wasting any water.

A $3 / 4$-inch-diameter copper pipe, the sampling line, taps the 4-inch pipe on the discharge side of the injection pump (pl. 1, fig 5). This line diverts a small quantity of the water to the automatic waterquality monitors. (See "Monitoring Instrumentation, Water Quality.") After passing through the monitors, this water is discharged to waste.

On its way to the injection well, the water next passes through a magnetic flowmeter. Directly beyond the flowmeter is a 6 -inch section of clear plastic pipe, through which the water can be observed. The water then enters the injection well through one of the three openings described in "Components of the Injection Facility, Injection-Well Complex."

\section{REDEVELOPMENT SYSTEM}

Details of the redevelopment system are shown schematically in figure 3 and plate 1 . The major element of this system is a vertical deep-well-turbine pump, which is suspended in the injection well at a depth of 150 feet. The 45-inch-long pump consists of five 10-inch-diameter bowls. It has a 5-foot tailpiece and is powered by a 50-hp constant-speed electric motor positioned above the well. The motor is connected to the pump by a shaft inside a 6 -inch-diameter epoxy-coated steel-pump column.

When the water pumped from the well reaches the top of the column, it is piped through the redevelopment line toward the flowmeter (pl. 1). Before reaching the flowmeter, a small quantity of water is diverted by a $3 / 4$-inch-diameter copper pipe to the water-quality monitoring system.

Beyond the sampling line, the diameter of the discharge pipe decreases from 6 to 4 inches. The water at this point can be routed back into the shallow or the deep injection lines. This ability to circulate water within the well is of advantage when the well is being treated with chemicals. When not being recirculated, the water next passes through the redevelopment flow-controlling device. This device is a pneumatically operated butterfly valve that can control the rate of flow within the range from 200 to $1,000 \mathrm{gpm}$. The water next flows through the flowmeter, and from there it flows either to waste or to the storage tank.

\section{FLOW CONTROL}

The principal element in the flow-control system, shown schematically in figure 6 , is the magnetic flowmeter. The flowmeter is positioned so that it can 


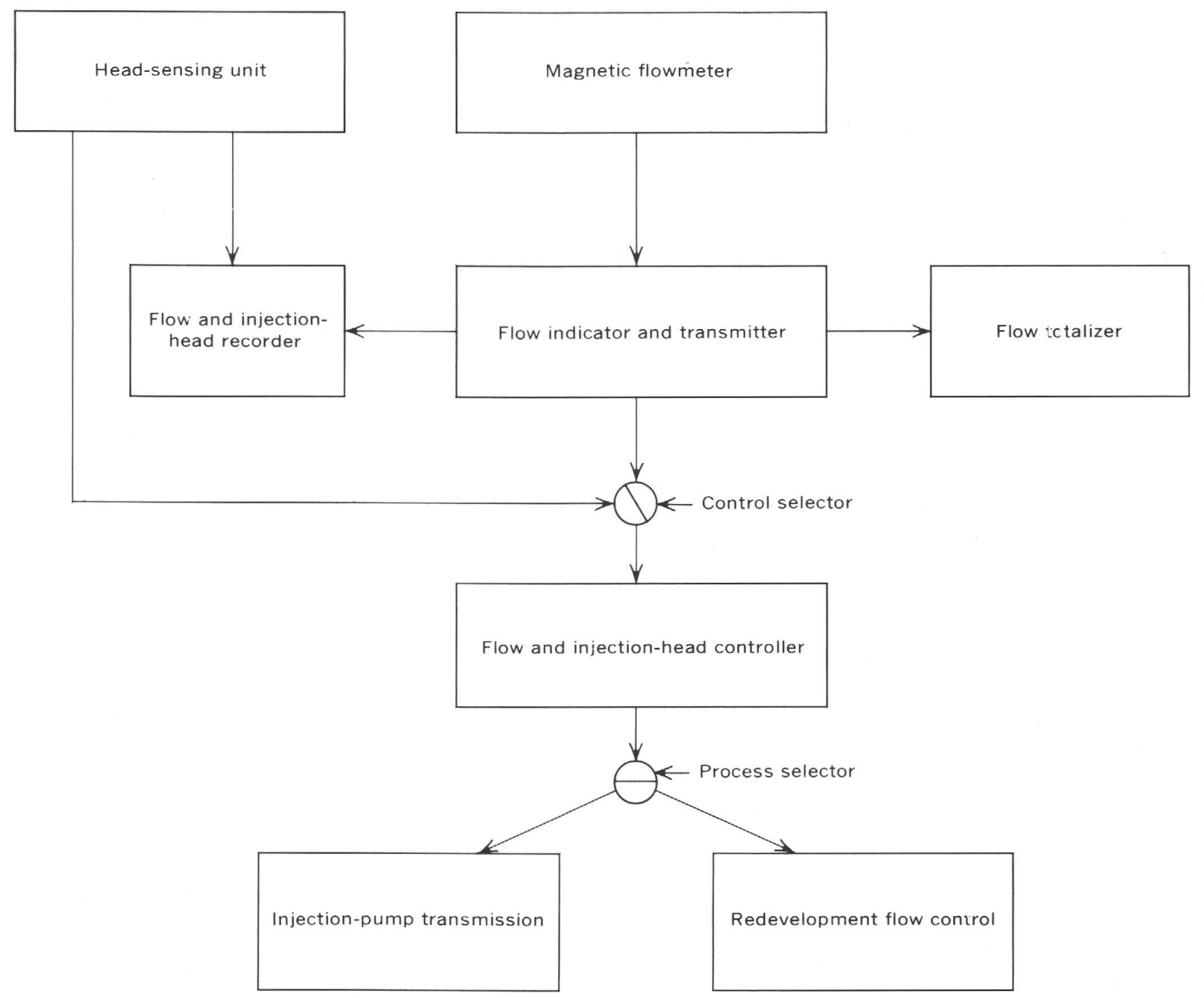

FIGURE 6.-Schematic showing the operation of the flow-monitoring and flow-controlling systems.

measure either injection or redevelopment flow. (See pl. 1.) The flowmeter senses the flow and produces an electrical signal proportional to the rate of flow. This signal is sent to a transmitter that converts the electrical signal into a pneumatic signal and then sends the signal to a pneumatic-indicating control station in a console (fig. 7) on the main floor of the wellhouse. All the flow-monitoring and flow-controlling devices are pneumatically operated. A compressor in the basement of the wellhouse supplies the compressed air. The discharge of the compressor goes into a drying unit to extract any water vapor that might interfere with the operation of any of the instruments.

Pneumatic signals indicating both the rate of flow and the head (on injection only) in the injection well are fed into the control station, and control signals are directed from it to the pump transmission or the redevelopment flow-control valve. The desired rate of flow, or the desired head during injection, is entered as a manual setting by adjustment of a scale until the required rate of flow or the head appears behind a marker on the instrument face. The measured value of flow or head is indicated by the position of another marker against the same scale. When the two markers coincide, the control variable is at the required value; when they do not coincide, adjustment of the control signal occurs in the direction required.

When constant flow-rate control is desired, the control selector (figs. 6 and 7 ) is positioned so that an air valve allows the signal originating in the flowmeter to be transmitted to the controlling mechanism. When the control selector is set for constant- 


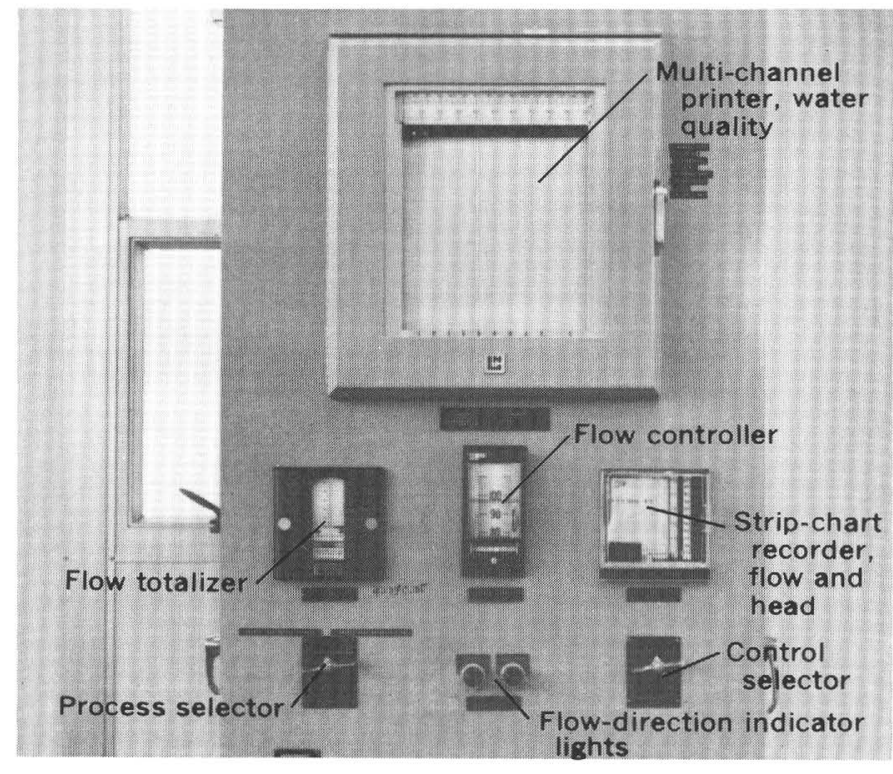

FIGURE 7.-Flow-controlling and flow-monitoring console in wellhouse.

head control, the signal from the flowmeter is blocked from the controlling mechanism. Instead, a pneumatic signal indicating head in the injection well is transmitted in its place. This latter signal originates in the pressure-sensing unit connected to the deep manometer tap of the injection well. Constant-head control can be accomplished only during injection. To date (1972), it has not been necessary to maintain a constant injection head. Therefore, only constant flow-rate control has been used.

The controlling mechanism makes adjustments to the flow as needed by sending an air signal through the process selector, where a second air valve directs the signal either to the servo-mechanism regulating the injection-pump transmission or to the redevelopment flow-control valve. When the process selector is set for injection flow, maximum air pressure from the plant supply is directed to the pneumatic cylinder controlling the redevelopment flow-control valve. This arrangement keeps the valve in a fully open position so that it does not interfere with the injection flow.

\section{OBSERVATION WELLS}

The observation-well network was designed so that heads and water quality could be monitored within the injection zone and also in the beds above and below the injection zone. The locations of the 18 observation wells in relation to the injeetion well are shown in figure 8 . The vertical distribution of the observation-well screens in relation to the injectionwell screen is shown in figure 9.

The observation well N7885 is closest to the injection well and is screened in the filterpack of the injection well (figs. 3, 8, and 9). Three other observation wells are screened in the same stratigraphic interval as the injection well (figs. 8 and 9, table 1 ). These wells are 20,100 , and 200 feet radially away from the injection well. Three additional observation wells at distances of 20,100 , and 200 feet radially away from the injection well are screened in a zone about 60 feet below the bottom of the injection-well screen. Two other wells 20 and 100 feet radially away from the well are screened in a zone about 110 feet above the top of the injection-well screen.

TABLE 1.-Selected construction details of test and observation wells at the Bay Park artificial-recharge site

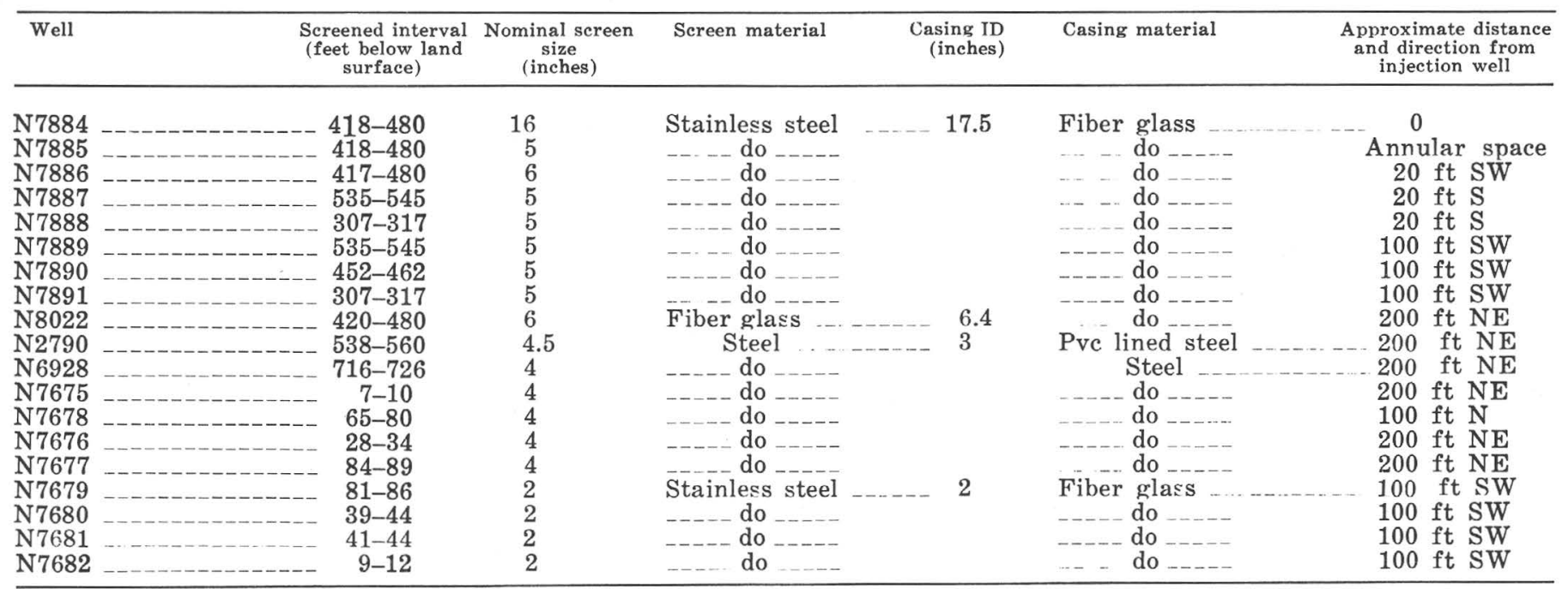




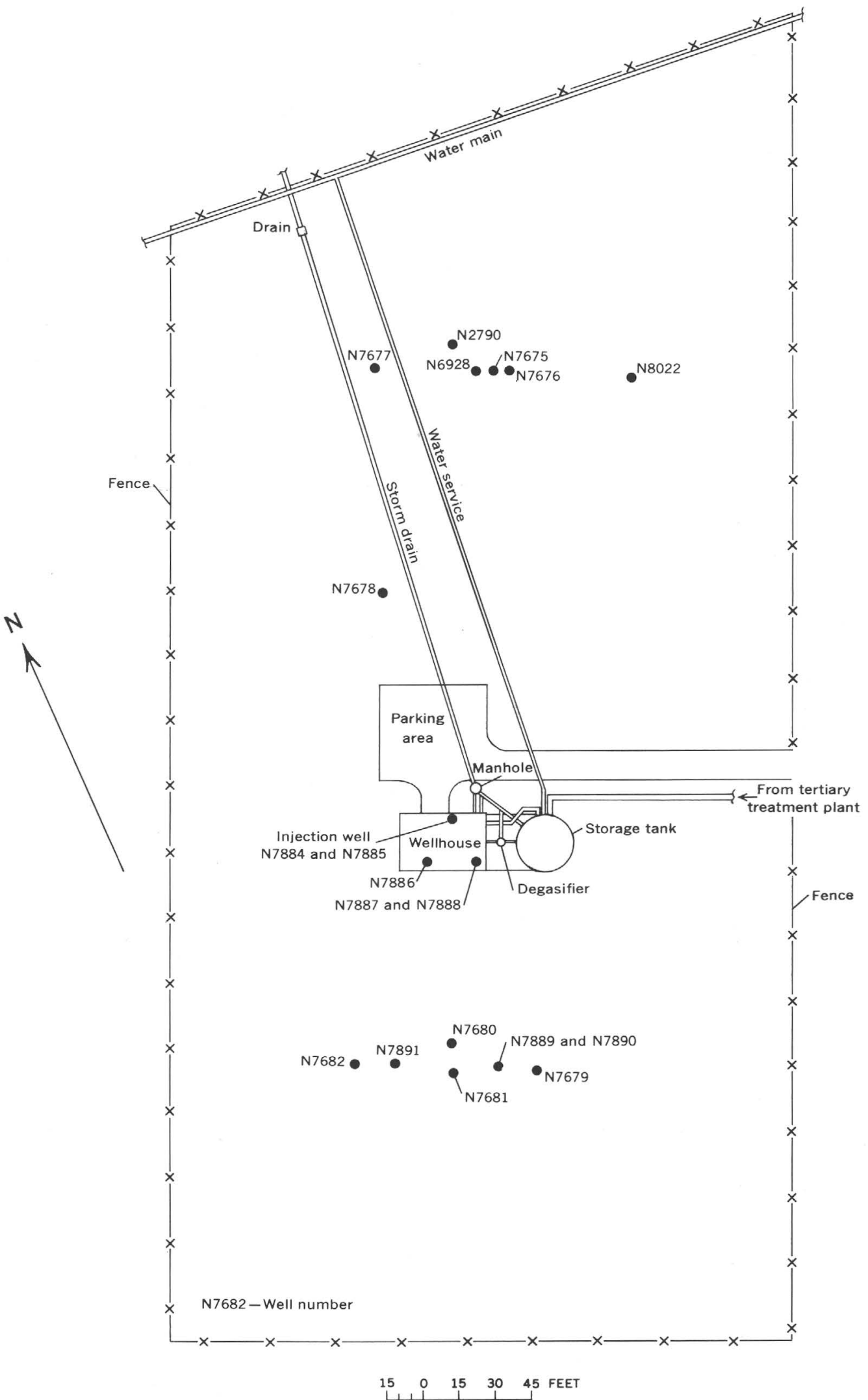

FiguRE 8.-Location of observation wells, structures, and external piping at the artificial-recharge site. 


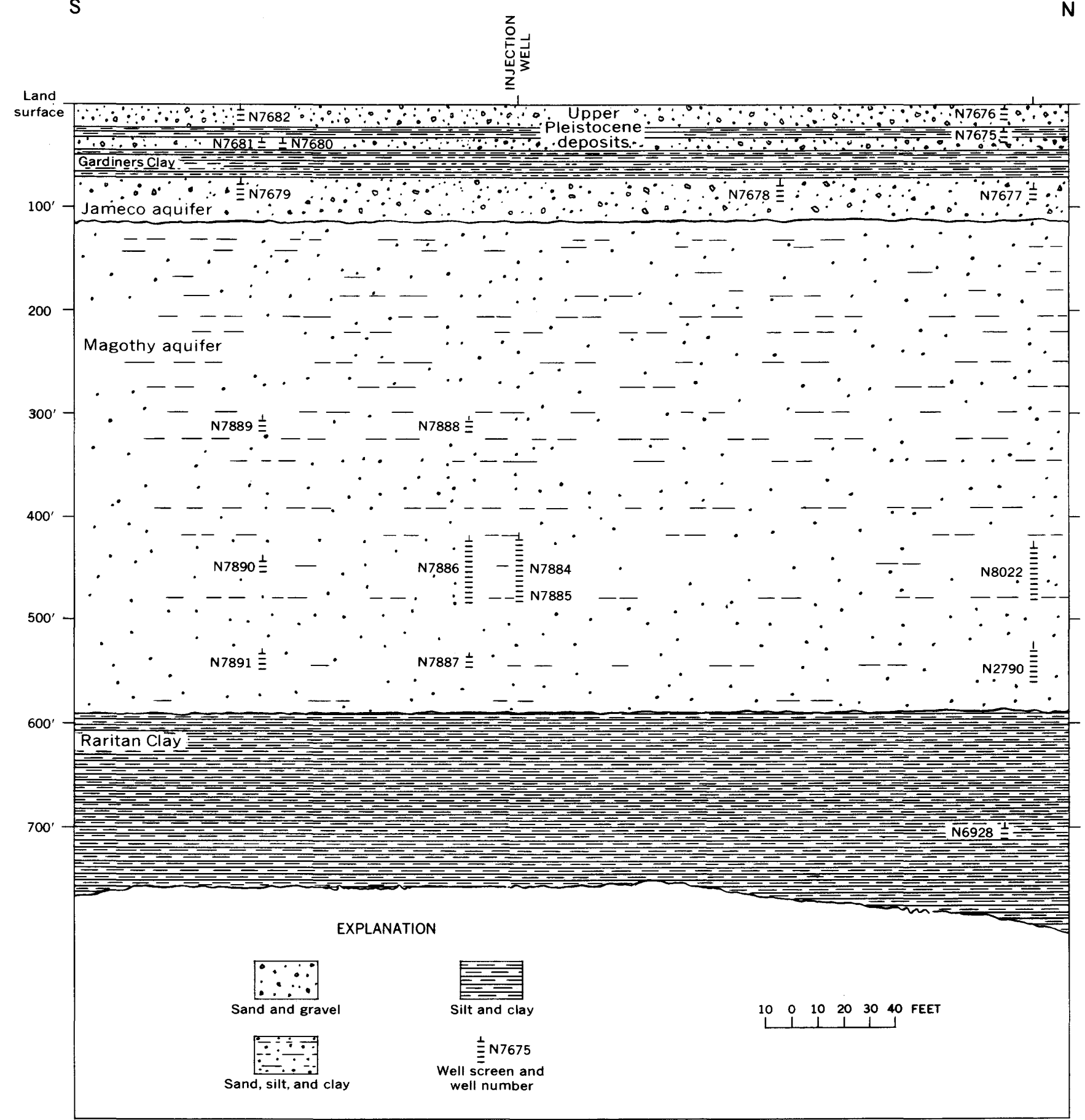

FIGURE 9.-Hydrogeologic section of artificial-recharge site showing vertical and horizontal distribution of the observationwell screens in relation to the injection-well screen.

\section{MONITORING INSTRUMENTATION}

\section{FLOW}

The rate of flow during either injection or redevelopment is continuously monitored by the magnetic flowmeter. The signal from the magnetic flowmeter is displayed in a gallon-per-minute readout form on four devices: the flow-control transmitter on a wall in the basement of the wellhouse, the control unit, a strip-chart recorder, and a totalizer housed in the console (fig. 7) on the main floor of the wellhouse. The totalizer also monitors the total gallonage pumped.

Direction of flow, either injection or redevelopment, is indicated by direction lights on the control transmitter and on the console. 


\section{WATER QUALITY}

Various physical- and chemical-quality parameters are monitored automatically by a series of instruments connected to the sampling line (pl. 1, fig. 10). The monitors measure dissolved-oxygen content, specific conductance, $\mathrm{Eh}, \mathrm{pH}$, chlorine residual, turbidity, and temperature. A record of these parameters plotted against time is kept by a multichannel, strip-chart recorder housed in the control console (fig. 7). The monitors are calibrated periodically by the use of standard analytical techniques on samples of water flowing through them.

The sampling line normally receives water either from the injection line or the redevelopment line. At times, water from observation wells N7885 or N7886 has been routed through the monitors, and, if desired, any of the other observation wells may also be connected to the automatic monitors by means of temporary piping. Valves on lines leading from the various sources control the flow to the monitoring system. Usually water from only one source is run through the monitors at a time, but, if desired, some monitors can be hooked up to one source while other monitors are connected to another source.
A submersible pump is installed in observation well N7886, which is 6 inches in diameter and 20 feet from the injection well. The pump is contained within a $4 \frac{2}{5}$-inch fiber-glass-reinforced epoxy pipe suspended in the well to a depth of 17 feet. From here a 11/4-inch pve pipe extends to a depth of 450 feet, roughly the midpoint of the screen. This arrangement permits the sampling of water from the screen zone without the need to evacuate the column of water in the well casing. Hence, very low discharges can be employed in sampling the well, and the accompanying distortion of the flow pattern around the well is minimized. During injection tests, the well is pumped continuously at a rate of 1 to 2 $\mathrm{gpm}$, and specific conductance of the water is determined frequently. The specific conductance of the water from the Magothy aquifer is less than $\mathbf{4 0 0}$ $\mu \mathrm{mhos} / \mathrm{cm}$ (micromhos per centimeter), whereas that of the treated sewage is 700 to $800 \mu \mathrm{mhos} / \mathrm{cm}$. Hence, the arrival of the injected water is readily indicated by a rise in specific conductance.

None of the other observation wells has a permanent pump. A portable downhole continuously reading conductivity meter is lowered into the more dis-

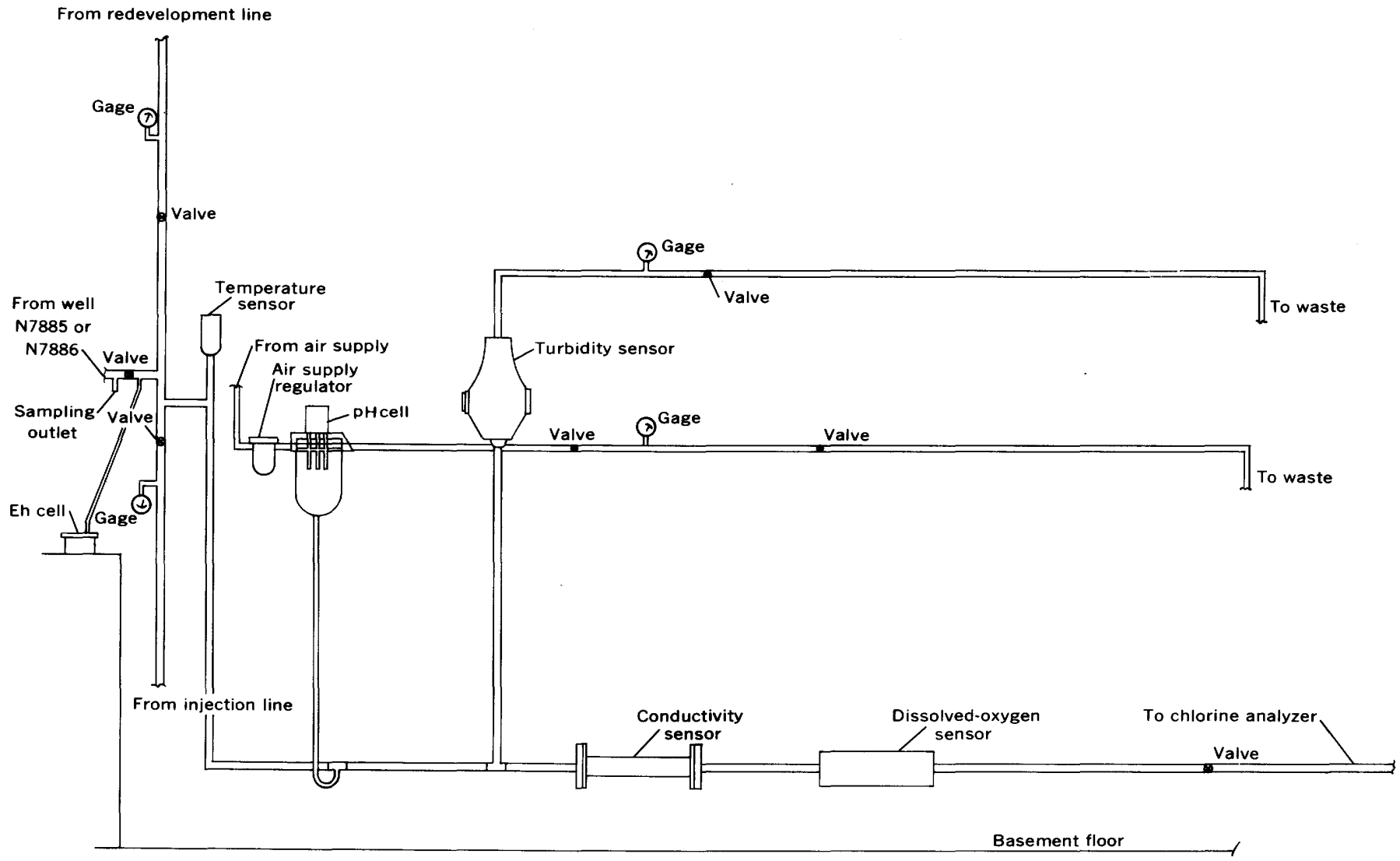

FIGURE 10.-Schematic diagram of sampling line for continuous monitoring of water quality. 
tant wells. When a significant rise in specific conductance is noted, indicating the arrival of the injected-water front, the instrument is removed and placed in a more distant well. A suction-lift pump for collection of water samples is then installed temporarily in the well.

Calibration of the automatic physical- and chemical-quality monitors and some chemical and bacteriological analyses are made in a small laboratory in the wellhouse.

\section{HEAD GHANGES}

Changes in head in and around the injection well are related to the ability of the aquifer to transmit either the injected water or the water pumped from the aquifer. In addition, excessive rises in head in the injection well are evidence of clogging. Two types of instruments are being used to monitor the changes in head in the injection well and in the observation wells-manometers and float-actuated water-level recorders.

Two pairs of manometers monitor the head in the injection well. Two other pairs of manometers tap wells N7885 and N7886. A set of water manometers is used until the head reaches about 18 feet; a set of mercury manometers is used at higher heads. The manometers are grouped together in two sets so that simultaneous readings can be made for the four taps.

Water levels in all the observation wells, except the annular-space well, are monitored with continuously recording float-actuated gages.

The head in the Magothy aquifer at Bay Park is affected significantly by changes in both barometric pressure and in tidal level in nearby estuaries. Therefore, it is sometimes necessary to remove these interferences before changes in head related to pumping or injection can be evaluated. A microbarograph records barometric fluctuations. Tidal changes are monitored with a pair of float-actuated waterlevel recorders set in stilling wells at the bay shore, which is less than half a mile south of the injection plant.

\section{EQUIPMENT PERFORMANCE}

To date (1972) 14 injection tests with durations from 2 to 33 days have been completed. In addition, numerous pumping tests have been made to redevelop the injection well and to evaluate changes, or lack thereof, in the hydraulic characteristics of the well and (or) the aquifer. Experience acquired during this testing indicates that, in general, the plant design has been suitable for making and closely observing the intended experiments. However, several minor modifications have been made to improve the operation of the plant. These modifications, as well as several strengths or weaknesses of various plant components, are described in the following paragraphs.

Most of the piping in the plant was pvc pipe designed to withstand anticipated line pressures. However, the pve pipe has ruptured in two places. Pipe fatigue caused by intermittent vibrations, possibly generated by the pumps, may have caused the failures. The damaged sections of pvc pipe have been replaced with epoxy-coated steel pipe.

Pump vibration probably also caused the development of a crack in the epoxy-cement bond between the injection-well casing and the flange ring at the well head. Originally, the flange ring was simply joined to the top of the fiber-glass casing with epoxy cement. After the crack developed, the flange ring was joined to the casing by a fiber-glass-reinforced epoxy joint made up on the inside of the well casing and overlapping the flange ring.

Problems of freezing and cracking of valves and of controlling apparatus associated with the degasifier were experienced during the first winter's operation. Originally the degasifier was not enclosed, but later much of the degasifier and all the controlling apparatus were enclosed in a heated extension to the original building.

Another problem related to the degasifier was the inability of the vacuum lift to maintain the desired flow rate to the degasifier. This deficiency was rectified by installation of a centrifugal booster pump on the line between the storage tank and the degasifier.

Capability of the redevelopment system is somewhat less than necessary to restore well capacity lost during injection. The maximum discharge of the redevelopment pumping system is $1,000 \mathrm{gpm}$. This rate is $21 / 2$ to 3 times the rate at which water has been injected. Pumping of the injection well at rates up to $1,000 \mathrm{gpm}$ restored much of the specific capacity lost during injection because of clogging phenomena. Some residual loss in specific capacity has persisted after most of the injection tests. A greater ratio of pumping rate to injection rate might have restored the efficiency of the well more completely.

In addition to serving as a reservoir for the water to be injected, the 50,000-gallon storage tank has been used in calibrating the magnetic flowmeter. It has also proven useful as a mixing vat for chemical solutions, such as sodium hypochlorite, that have been added to the injection well. 
Emplacing chemical solutions in the screened interval of the injection well has been facilitated by injection of these solutions through either the observation well in the filterpack or through the deep pressure-measuring pipe that enters the injection casing just above the well screen. Without these means of emplacing chemicals at the screen of the injection well, cumbersome drop-pipe installations within the injection well would have been necessary.

The observation-well network around the injection well has made possible a detailed evaluation of the hydraulic effects of injection with the treated sewage. In addition, the network has permitted detailed appraisals of the microbiological and the geochemical aspects of the injection program. The small laboratory on the site has facilitated collection and treatment of water samples for chemical and microbiological analyses. In addition, the laboratory has helped in maintaining calibration of the automatic water-quality monitors.

The Bay Park injection facility is the result of a thoroughly planned and well funded project. Its design has been generally adequate to meet the major objectives of the project_to define the hydraulic and the geochemical problems connected with the injection of tertiary-treated sewage into the Magothy aquifer. Results of this (1972) ongoing investi- gation have been published in several reports, some of which are included in the references of this report.

\section{REFERENCES CITED}

Cohen, Philip, and Durfor, C. N., 1966, Design and construction of a unique injection well on Long Island, N.Y. in Geological Survey Research, 1966: U.S. Geol. Survey Prof. Paper 550-D, p. D253-D257.

1967, Artificial-recharge experiments utilizing renovated sewage-plant effluent-a feasibility study at Bay Park, New York, U.S.A.: Internat. Assoc. Sci. Hydrology, Pub. No. 72, p. 194-199.

Perlmutter, N. M., Pearson, F. J., and Bennett, G. D., 1968, Deep-well injection of treated waste water-an experiment in re-use of ground water in western Long Island, N.Y.: New York State Geol. Assoc. Guidebook, 40th Ann. Mtg., p. 221-231.

Peters, J. H., 19є8, Supplemental water supply by tertiary treatment and recharge, in Fourth American Water Resources Conference Proceedings: Am. Water Resources Proc. Ser. no. 6, p. 330-344.

Peters, J. H., and Rose, J. L., 1968, Water conservation by reclamation and recharge: Am Soc. Civil Engineers Proc., Jour. Sanitary Eng. Div., v. 94, no. SA4, p. 625639.

Vecchioli, John, 1970, A note on bacterial growth around a recharge well at Bay Park, Long Island, N.Y.: Water Resources Research, v. 6, no. 5, p. 1415-1419.

Vecchioli, John, and Ku, H. F. H., 1972, Preliminary results of injecting highly treated sewage-plant effluent into a deep sand aquifer at Bay Park, Long Island, N.Y.: U.S. Geol. Survey Prof. Paper 751-A, 14 p. 

